\title{
Nestroy meets Wagner. Parody as an alternative literary concept and a test bench for stylistics
}

\author{
Oswald Panagl \\ University of Salzburg \\ oswald. Panaglesbg.ac.at
}

\author{
Christina Katsikadeli \\ University of Salzburg \\ Christina.Katsikadeli@sbg.ac.at
}

\begin{abstract}
The language peculiarities of Johann Nepomuk Nestroy (1801 - 1862) - as used in his Possen, parodies and dramas - are considered the literary highlights of the Old-Viennese Volkstheater. A comprehensive study, which explores the linguistic facets of J.N. Nestroy's theatrical corpus from the point of view of modern linguistics, still remains a desideratum. In the present paper we investigate Johann Nestroy's critical confrontation with the music and the libretti of Richard Wagner's romantic operas Tannhäuser and Lohengrin, which aims at targeting the medieval milieu, the 'precarious' theme (in the cellar of Venus!), but especially the long-winded stage directions, the (hyper)archaic word choice, the exaggerated epithets, the pathetic diction, and not least, the 'rampant' metaphors in these music dramas. By making use of methods and tools employed by corpus linguistics, the objective of this paper is to search for general and specific patterns of Nestroy's parodies, not only in representative examples, but also to classify them within the genre and interpret them according to a set of linguistic parameters.
\end{abstract}

\section{Introduction}

Functioning as 'comparative yardsticks', parodies (and travesties) of other stage plays - as a rulemock salient dramaturgical moments as well as excessively used linguistic features, such as neologisms, figures of speech, stylistic devices and other experiments and transgressions beyond the norms of the literary Vorlage. At the same time, however, these varieties implicitly attest to the level of awareness, the rank(ing) and the prominence of the mockingly treated pattern or "archetype", since the satire can find its complete expression only under these conditions. In the history and research of the genre 'parody', two linguistically possible readings of the original Greek compound $\pi \alpha \rho-\omega \delta i ́ \alpha$ are reflected: the preferred older interpretation as 'song in contrast', focuses on the mockery and trivialization of one - in the most cases - sublime and prestigious model, to which the parodying author indirectly pays his reverence at the same time. The mismatch between 'higher' form and style and 'low' content differentiates the parody from the travesty (actually 'disguise'), where the relationship is reversed.

More recent scholarship argues for another explication of the term, namely as 'the song next to [the original]', cf. the Greek preposition para in the sense of 'next, nearby'. Thus, the parody serves intertextuality as a repetition with a difference and appears as an operative term of the "transcontextualization', i.e. the transfer and the different interpretation of a text(-excerpt) into a new context. In the following passages we attempt to localize and sum up the linguistic elements, which serve the intermediation between these 'notorious differences'.

\subsection{Methods}

In trying to answer the questions raised by the relation of a parody to its original, we initially rely on, but at the same time go beyond the insightful observations concerning the language of Nestroy found in publications, such as Hein (1968), (1970), (1975), and more recently, Hunger (1999). In addition, previous work from the point of view of linguistics (cf. i.a. Panagl 1983, 2005, 2007;) and the first corpus-based studies by Dressler \& Tumfart (2017ab and Dressler, Tumfart and Hanneschläger in this volume) on occasionalisms in Nestroy's language, serve as a starting point of this investigation and act as reference for Nestroy-specific phenomena of language structure and use, which deserve more detailed study and analysis within the general framework of corpus linguistics and historical

\footnotetext{
${ }^{1}$ Cf. also Panagl (2009, 40-43).
} 
sociolinguistics. For this purpose, we tried to examine Nestroy's language structure and use in his parodies not only by focusing on isolated phenomena but also within a 'set' of features, and further, we attempted an extension of the parameters according to several sociolinguistic aspects (see under 2.3 below).

The state of the art as well as the outlines of our corpus-based analyses and the methods used can be summarized as follows: Nowadays, advanced detailed research on the language use in Nestroy's plays can be enormously enhanced by a number of recent major accomplishments in the study of Nestroy's work, such as: a) The completion of the new Historical-Critical Edition of the Nestroy corpus (1977-2012), edited by Hein, Hüttner, Obermaier and Yates (under the patronage of the International Nestroy Society), hence HKA (Historisch-Kritische Ausgabe) b) the digital database and concordance provided online by the International Nestroy Society ${ }^{2}$ and the digitalisation of the corpus (the complete 'Rommel edition, ${ }^{3}$ at the Academiae Corpora at the Austrian Academy of Sciences in Vienna (ÖAW) ${ }^{4}$. Modern computational tools open up new possibilities to analyze the language related to the characteristics of language structure and use. In order to answer the specific research questions related to grammar, pragmatics, and semantics the following steps were undertaken for the preparation of the Nestroy's Wagner Parody Corpus:

a) we digitalised both Nestroy-parodies Tannhäuser und Lohengrin (according to the HKA) and the respective Wagner's operas (according to the online available edition in the Richard Wagner TextDatenbank $^{5}$ ) and we automatically annotated the corpus with POS-tagging, using the Sketch Engine ${ }^{6}$ tagger. A further parameter has been added manually: -comp for compounds, -occ. for occasionalisms, -tech for technical terms, -hapax for hapax legomena in the entire Nestroy-Corpus.

b) Parallel to the above mentioned online-database by the International Nestroy Society, we made use of the automatically generated concordances, which we created by using the Sketch Engine tool.

c) In addition to the automatic POS-tagging, we manually annotated the passages according to the dramatis personae, following the annotation concept for theatrical, and in general literary corpora, according to Culpeper 2001, by adding mark-ups based on the initial letter of each character's name in capital, e.g. WOLFRAM $\langle\mathrm{W}\rangle\langle/ \mathrm{W}\rangle^{7}$. At the same time information on: male/female speech and register (low/high) has been added. In the latter category low refers to whole passages in the Viennese dialect as well.

As a matter of course, Nestroy's language oscillates between Viennese and ironically used standard or archaic language everywhere in his plays, but we highlighted those cases where he 'rewrites' whole passages and Wagner's operas and transfers them into a dialectal but also rather vulgar Viennese setting, e.g. compare the highlighted forms below, which deviate from the Standard High German idiom:

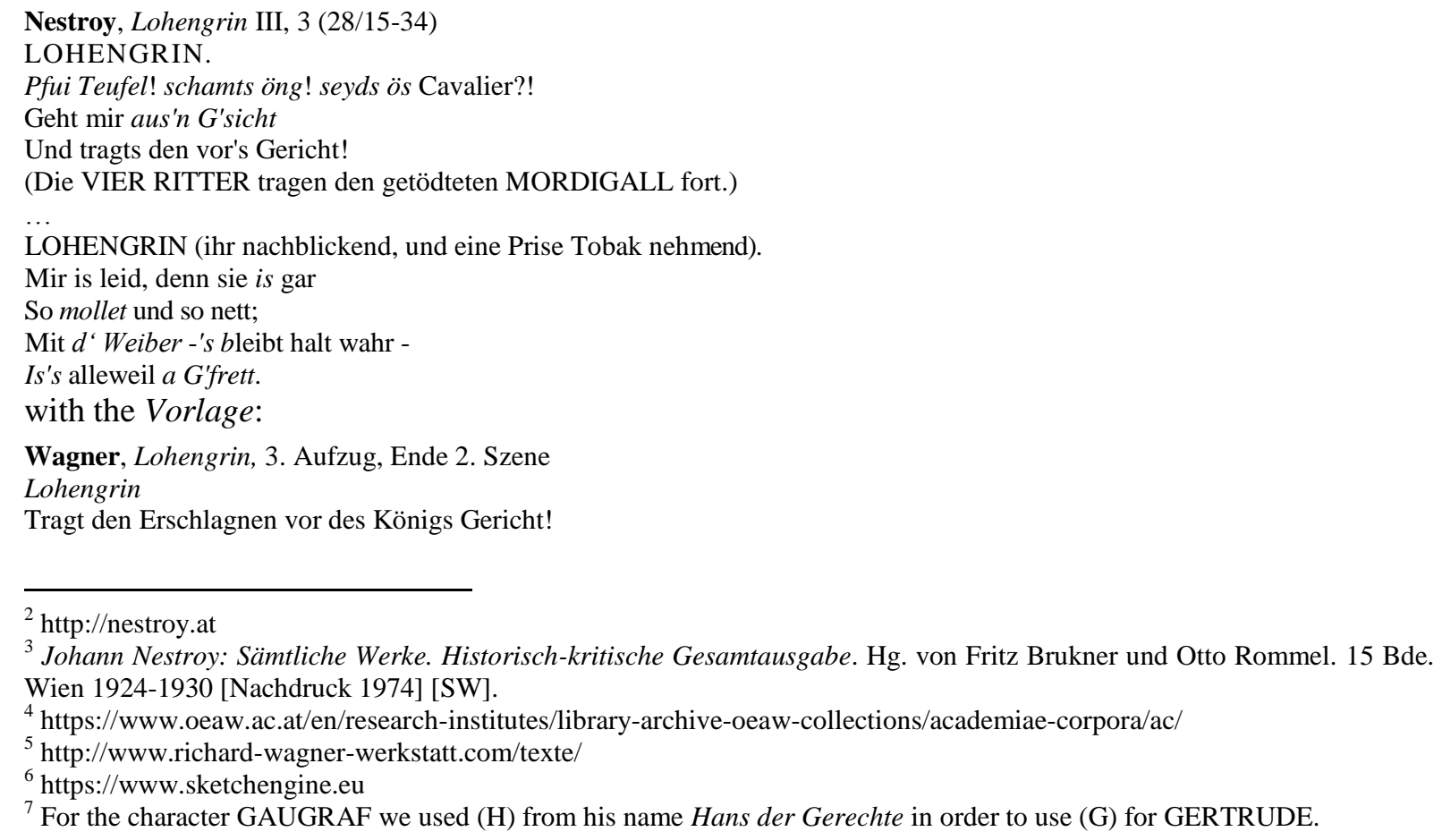

\footnotetext{
${ }^{2}$ http://nestroy.at

${ }^{3}$ Johann Nestroy: Sämtliche Werke. Historisch-kritische Gesamtausgabe. Hg. von Fritz Brukner und Otto Rommel. 15 Bde. Wien 1924-1930 [Nachdruck 1974] [SW].

${ }^{4}$ https://www.oeaw.ac.at/en/research-institutes/library-archive-oeaw-collections/academiae-corpora/ac/

${ }^{5} \mathrm{http}: / / \mathrm{www}$.richard-wagner-werkstatt.com/texte/

${ }^{6} \mathrm{https}: / /$ www.sketchengine.eu

${ }^{7}$ For the character GAUGRAF we used (H) from his name Hans der Gerechte in order to use (G) for GERTRUDE.
} 
Die Edlen nehmen die Leiche Friedrichs auf und entfernen sich mit ihr durch eine Tür des Hintergrundes. Lohengrin läutet an einem Glockenzuge; vier Frauen treten von links ein.

(zu den Frauen)

Sie vor den König zu geleiten,

schmückt Elsa, meine süße Frau!

Dort will ich Antwort ihr bereiten,

daß sie des Gatten Art erschau'.

Previous research has often employed the cover terms register and genre to refer to the text categories occurring in corpora, where the two parameters are distinguished as two approaches or perspectives for the analysis of text varieties, cf. Biber $(2010,241-242)$. For various reasons, most corpus-based studies of text varieties have taken a register perspective rather than a genre perspective. That is, corpora have often been composed of text excerpts rather than complete texts, a methodological choice that enabled researchers to identify the linguistic features that are used pervasively throughout texts (register features), but at the same time it did not made possible to identify conventional features that are used at a particular place in a complete text (the genre perspective). And for this reason, genre studies must be based on an exhaustive analysis of complete texts from the variety. At this point, we want to underline that our study should be understood as a corpus-based 'mixed investigation' on register and genre at the same time. While the register perspective focuses on the pervasive linguistic characteristics of parody and on how those features are functionally connected to the situational context, the analysis of genre concentrates the typical structural and language features, which conform to the culturally expected way of constructing texts belonging to the variety 'parody' ${ }^{8}$. Therefore, we searched for and summarised a 'set' of linguistic features, which occur in the entire Nestroy Parody Corpus, including the list of the dramatis personae (2.1.) and the stage directions (2.2.), within their 'parody-specific' registers (2.3.).

\subsection{Nestroy's Wagner Parody Corpus}

Our corpus is a mini-size corpus: each Nestroy parody consists of about 5,500 words (Lohengrin 5,407 words; Tannhäuser 5,606 words). Wagner's Lohengrin displays about twice the lenghth $(12,214$ words) and Tannhäuser is about 2000 words longer (7,840 words) than its parody. Some brief information about the composition and reception of Nestroy's parodies:

Tannhäuser, from the year 1857, is probably Nestroy's most prominent contribution to this genre and carries the subtitle „Zukunftsposse mit vergangener Musik und gegenwärtigen Gruppierungen“ (in three acts; music by Karl Binder). Nevertheless, it has been this play in particular, where Nestroy's authorship was not left without controversy among the early research on Nestroy. Otto Rommel points out in the appendix of the sixth volume of his edition $(1962,740)$ that the Tannhäuser-parody should be considered a play by Nestroy only with reservations. In this case Nestroy follows the four-act students-pub parody ('Bierulk') by the medical doctor Dr. H. Wollheim from Breslau (1854).

Meanwhile, the initial doubts about Nestroy's authorship have been eliminated. In this regard we refer to Peter Branscombe, the editor of the HKA, who draws attention not only to typical 'Nestroy-like' neologisms, but also to relevant passages in the acts of the censorship authorities.

However, the fact that Nestroy did know and use the Wollheimer-parody has been a crucial prerequisite for the study of Nestroy's own Tannhäuser. Previous scholarship on Nestroy has already conducted a thorough comparison between Wollheim's text and the Viennese version. According to the findings it is clear that despite the extensive adaptation of the Northern German original by Wollheim, the Viennese Tannhäuser offers original 'Nestroyan' style. Further, according to Branscombe (2000, 4), Nestroy treated Tannhäuser in a similar way as his other plays, which were based on a Vorlage: he always surpassed the finesse of the borrowed elements and improved the adopted ideas thanks to his own creativity.

The Viennese first performance of Wagner's opera Lohengrin was on the 19th August 1858 in the k.k. Hofoper (at that time in the Theater am Kärntnertor), while Nestroy's parody in Carltheater was performed on the 31 of March 1859 for the first time. Since both the success of Lohengrin and the critiques were not even vaguely close to Tannhäuser's, one could be tempted to say that, as far as the

\footnotetext{
${ }^{8}$ Cf. Biber (2010, 241): These language features are conventionally associated with the genre, for example, scientific research articles conventionally begin with an abstract, followed by the main body of the text, which is usually structured as four main sections - Introduction, Methods, Results, Discussion - which is in turn followed by the references.
} 
linguistic finesse is concerned, the latter was more elaborate than the later Lohengrin, the authorship of which cannot be questioned since it displays Nestroy's own handwriting. Later scholarship on this topic tends to treat Lohengrin as a rather underestimated work, which did not manage to reach its contemporary audience. ${ }^{9}$ Concerning the present investigation, we attempt to decide which of the above evaluations is suitable by comparing the features and registers occurring in the two plays against one another. (see under 3.3 below).

\section{Wagner vs. Nestroy in Tannhäuser and Lohengrin}

\subsection{Parody of the dramatis personae}

Naming is a wide-spread comic device, known both from the every-day speech, and from the more elaborate 'speaking names' of literary authors across all times and languages. ${ }^{10}$ The use of names in literature is largely determined by the nature and demands of the genre. In general, naming in comedy is a much more original process, which no longer relies on tradition for its heroes and their names, but on contemporary realities and on the poet's fantasy. In parody, however, we find ourselves on completely different ground: since naming focuses on mocking the original, i.e. in our case the 'epic' names in Wagner's operas. In more or less straightforward ways, all names used by Nestroy appeared to be richly evocative, since every protagonist's name is significant and carries dramatic weight, but at the same time it also retains its reference to Wagner's original characters.

\section{Parody of real persons:}

T: Wolfram Dreschenbach ${ }^{11}$ ( Wolfram von Eschenbach) by changing Esche(n) 'ash-tree' in the scholar's name into dreschen 'threshing', coll. also 'walloping', or perhaps as used in Phrasen dreschen 'to talk in platitudes' and similar expressions trigger the connotation of 'loud' and 'monotonous' chanting; Walter Finkenschlag ${ }^{12}$ ( Walter von der Vogelweide 'bird-meadow'), both members of the compound have been replaced by Fink 'finch' and Schlag, in this case 'twitter', or even in the sense of this word as used in Austrian place names ending in -schlag 'place after a vegetation clearance' replacing Weide 'pasture, meadow' (cf. Biber-schlag, Upper Austria).

Folk-comedy/Austr. dial. rural names and titles as low register contradictions to the original noble characters:

T: Taubenklee Fridolin is the name with the most obscure motivation: probably a further rendering of Vogelweide, consisting of the bird name Taube 'pigeon' and kle 'clover', synonymically or metonymically used for 'grass'. The second name Fridolin might refer to an Irish saint from the $7^{\text {th }}$ c., who was a patron of the pasture (cf. Branscombe 200, 170); Langraf Purzl: the landgraves name reminds of purzeln 'to fall, overturn' and displays the dial. diminutive suffix - $l$; finally, the speaking name of the of the landgrave's funeral herold Katafalker contains the noun Katafalk 'a base frame or a scaffold for the coffin'.

L: Pafnuzi: in Viennese dial. 'naive person, idiot; witless bigot' $<$ simple-minded giant in medieval Austrian folk tales. ${ }^{13}$

The title von Wetterschlund of the knight Mordigall is linked to the respective Wagner's character Friedrich von Telramund by interpreting the element -mund not in the meaning 'protection', which is the prototypical one for this group of popular Germanic names, e.g. Siegmund, Edmund, but as Mund 'mouth' and rendering it with Schlund 'throat, gullet; abysm'. The first element Wetter- 'weather', in Austrian German also used in the sense of Gewitter 'thunderstorm', probably connects the compound to the attested term Donner-schlund 'a gullet where thunder(-like) noise comes from' (i.a. of Vesuv, cf. Campe 1746 s.v.) and in this way, ideally completes the semantics of the first name Mordigall (<

\footnotetext{
${ }^{9}$ Cf. Schneider (1996, 106-109).

${ }^{10}$ Cf. e.g. for Aristophanic names, Kanavou 2010; for English literature, such examples as can be found in Shakespeare's comedies (Barton 1990: 107 ff.).

${ }^{11}$ The name also occurs in Wollheim's characters list.

${ }^{12}$ In Wollheim's parody: Walter von der Viehweide; in other versions: Berlin: W. von der Hasenhaide; Dresden und Leipzig: W. von der Vogelwiese.

${ }^{13}$ The name Paphnutius is of Egyptian-Coptic origin; the most celebrated personage of this name was bishop of a city in Upper Thebes in the early fourth century, and one of the members of the Council of Nicaea (325).
} 
Mord 'murder' + a rhyming with Nachtigall 'nightingale') as opposed to Hanns der Gerechte 'Hanns the Righteous', who in turn bears the element Vogel 'bird' in his title Mark- u[nd] Gaugraf von Vogelfingen ( Heinrich der Vogler, deutscher König)

\section{Rhyming/phonetic alternations:}

Next to Wolfram Dreschenbach in T, in L we find following word creations: Elsa von Dragant Tragant(wurzel) 'tragacanth' (Elsa von Brabant); der Hinundherrufer 'back and forth crier' mocks the medieval royal Heerrufer 'army crier'

Parody of Wagner's Zukunftsmusik:

Zukunfts- 'future' -ritter 'knights', -frauen 'women', -fräuleins 'young ladies', in contrast to Vergangenheitsdamen 'ladies of the past' (see also under 2.3.2.)

\subsection{Stage directions:}

Officialese, pedantic standard language and pathetic diction are a common device for style 'breaks' in Nestroy's theatrical plays ${ }^{14}$. As in Tannhäuser ${ }^{15}$, the verbose and tedious stage directions by Wagner have been targeted by Nestroy's parodying spirit in a similar way, by exceeding the original length with pleonastic details and expressions, while keeping the register 'high' (e.g. the archaic -en-form for the oblique case in Gertrud's name), cf. the following passages:

Wagner (Lohengrin Ende Zweiter Aufzug)

Als der König mit dem Brautpaar die höchste Stufe erreicht, wendet sich Elsa in großer Ergriffenheit zu Lohengrin, dieser empfängt sie in seinen Armen. Aus dieser Umarmung blickt sie mit scheuer Besorgnis rechts von der Treppe hinab und gewahrt Ortrud, welche den Arm gegen sie erhebt, als halte sie sich des Sieges gewiß; Elsa wendet erschreckt ihr Gesicht ab. Vom König geführt, schreiten Lohengrin und Elsa dem Eingange des Münsters zu.

\section{Nestroy (Lohengrin Ende Zweites Bield)}

(Während des Chores ist Elsa nach der Thüre aus welcher sie gekommen (nach rechts) zurückgekehrt; ganz nahe schon an derselben blickt sie sich nach Gertruden um, welche an der ander[n] Seite im Vordergrunde steht, und' ihr verdächtige Zeichen und Wincke giebt. Lohengrin merkt dieß, und, nimmt eine drohende 'Attitude' gegen Gertruden an; diese mißt ihn mit höhnischer Gebärde, während Mordigall ihm mit der Faust hinterrücks droht, sich aber, als er sich bemerkt sieht, scheu zurückzieht. Während dieser Gruppe fallt der Zwischen-Vorhang.)

(Ende des 2ten Bieldes.)

\subsection{Linguistic registers \& features}

Hereafter, we attempt an overview of the parodistic elements, which have been applied by Nestroy in the main parts his two plays, which were actually performed on stage. For this purpose we utilize a typological framework, which is based on the major linguistic features and registers identified by classical philologists and historical linguists for the language of the Aristophanic comedies and summarised and expanded with sociolinguistic parameters by Andreas Willi in his seminal monograph "The Languages of Aristophanes" (2003).

The comparison of the 'Nestroyan' style with Aristophanes is not a novel proposal in the respective literature, as a matter of fact Nestroy's epithet was 'the Viennese Aristophanes'. Until now, however, we don't have a detailed comparison, which refers to the whole material, at our disposal. As expected, a one-to-one contrasting between Nestroy's penmanship and the Ancient Greek, so-called Attic Old Comedy is not always possible, but after listing and comparing the various features, we are in a position to realise, that the similarities between the two corpora strikingly outweighed the differences by far. We want to point out that we consider these similarities as linguistic-cognitive elements, which a playwright employs in order to make his/her different characters "tangible" for the audience. In our case, the time span, the different language and cultural setting, which separate Nestroy from Aristophanes, can be considered a methodological advantage, since this 'remoteness' allows us to assume a rather 'universal' typology of humoristic elements in theatrical plays and at the same time eliminate the possibility of copied elements.

Of course, in the case of the Nestroy Parody corpus, the relatively small chronological distance, which divides us from the playwrights times, allows us to securely recognise linguistic and cultural

\footnotetext{
${ }^{14}$ Und jetzt schreiten wir zur allseitigen Verschlafung der stattgehabten Mißliebigkeit („Heimliches Geld, heimliche Liebe, II,21); Meine durstigen Augen saugen das Strahlenmeer ihrer Züge (,Der Holländische Bauer“, I,6)

${ }^{15}$ Cf. Panagl (2009, 42, 45-47).
} 
anachronisms in respect to the archaic, medieval setting of Wagner's operas, a factor that is hardly traceable or even impossible in ancient corpora: for instance Nestroy, Lohengrin 12/3-40 uses the chlidren's speech and colloquial expression Dingsda 'thingummy' in the famous Wagner's aria „Zum Kampf für eine Magd zu stehen" and contrasts this expression with a knight, the 'old German times' and the archaic and pleonastic ehlichen Gespons 'marital spouse'

\section{LOHENGRIN.}

\section{...}

Wenn ich den Ritter Dingsda ('the knight thingummy') dort - wie heißt er denn geschwind? egal wenn mir auch der Nahmen nicht einfallt - besiege, Versprichst Du mir, daß ich Dich dann zum Dingsda ('whatchamacallit') - wie sagt man denn hier zu Land und in der altdeutschen Zeit? habs schon - zum ehlichen Gespons auch kriege?

And a few lines later he employs a cultural anachronism referring to the use of a 'passport'

Geheimniß muß von mir Dir Alles bleiben,

Was üblich ist, in's Tagzett'l einzuschreiben.

„,Gebursort, Alter, Stand, Hantierung, Heimatsschein,

Hat Paß von-,, und wie s' alle heißen, die Rubriken, -

Similarly, in Tannhäuser 15/27:

„Lass dich umarmen, Sängerfreund-doch warte-von wannen lautet deines Passes Karte?““

(where the officialese question alternates with the stylistically inappropriate, archaic interrogative adverb von wannen 'since when'.

Although the anachronistic elements are an important component of the parody, Nestroy seems to avoid overusing them (as it is apparent from the anachronism omissions in the Wollheimer's version).

\subsubsection{Technical vocabulary}

Technical or scientific terms, which do not belong to everyday speech and are therefore predestined to indicate different linguistic registers and the educational background of speakers. Whereas terminology is stylistically neutral in technical writings, it becomes stylistically marked ('obscure', 'funny', etc.) in non-technical genres such as comedy. Thus, certain forms of implicit comment on the technicality of a given word are more likely to occur in comedy than anywhere else.

Following Willi (2003, 65-69), we apply here three criteria of technicality, which are specific to comical plays ${ }^{16}$ : Because they do not form part of general language, technical terms are stylistically marked in comedy. Their markedness is exploited for comic (misunderstanding), stylistic (accumulation), and dramatic (characterization) purposes.

\subsubsection{Comic misunderstandings.}

If one stage character misunderstands the words of another character, this may indicate that these words were felt to be technical, especially if the speaker is a specialist of some sort and talks about his field. Of course, the audience must notice the misunderstanding and be able to infer the intended, technical, meaning from the context. Otherwise we must assume that the words were not technical and that the scene focuses on the linguistic incompetence of the addressee rather than on the vocabulary of the speaker. In most of the cases, comic misunderstandings lead to folk- or paretymological (re)interpretations by the addressee, which do not always involve the contrast between technical/scholarly vocabulary vs. naïve language usage/malapropisms. Since the noble characters in Wagner's operas are less suitable for the application of a 'classic' contrasting between learned and simple-minded stereotypes, Nestroy employs folk-etymology, learned paretymology and similar phenomena, not in dialogues, but within the lines of one character. Thus, the contradiction arises between the epic style of the Vorlage, which the audience has in mind, and the parody and not between the protagonists' interaction on stage, and after all, in accordance with the meaning of the term $\pi \alpha \rho \emptyset \delta i ́ \alpha$.

Undoubtedly, the most prominent example for Nestroy's mastery is his folk-etymology for the prototypical Wagnerian term Gral 'grail' in Lohengrins Gralserzählung:

\footnotetext{
${ }^{16}$ Cf. Willi $(2003$, 69) for a summary on the general criteria for the 'technicality' of terms: they are a) related to a specialist discipline; b) context-independent in meaning within that discipline; c) standardized in usage and at least ideally monosemous; d) expressively neutral; e) in non-technical environments like comedy rare and unambiguously associated with a specialist field, and, f) most importantly not actively used (though possibly understood) by the nonspecialist, and therefore subjectively classified as technical by the average native speaker.
} 
Wagner, Lohengrin, 3.Aufzug

drin ein Gefäß von wundertät'gem Segen

wird dort als höchstes Heiligtum bewacht:

Es ward, daß sein der Menschen reinste pflegen,

herab von einer Engelschar gebracht;

alljährlich naht vom Himmel eine Taube,

um neu zu stärken seine Wunderkraft:

Es heißt der Gral, und selig reinster Glaube

erteilt durch ihn sich seiner Ritterschaft.

Nestroy, Lohengrin 31/18-29.

Hoch steht ein Zauberschloß

Auf einem Felsen

Mitt'n in ein'n Feenhain,

Ganz ohne Gelsen.

D'rinn ein Schaz heißt der „Gral“

Niemst weiß weßwegen

Und der Gral allemahl

Bring! Glück und Seegen.

,Gral " kommt von ,Gralawat"

Und möglich is es,

Daß'n einst wer g'stohlen hat,

Man weiß nix G'wißes.

's Stärkt den ,Gral““ wunderbar

In Gral kommt von, Gralawat (31/26) the prestigious term, and as a consequence the entire song, is distorted by the association with the Viennese dial. lexeme gralawat 'to steal' $<$ Cech verb kradlovati 'to steal' (supine kradlovat), cf. also the Viennese dial. Noun Gralowad 'stealing, theft' (Branscombe 2001, 193).

In addition, as a true master of this device, Nestroy expands it in various situations beyond the main stream domains, such as technology, medicine or scholarship, for instance, even in the inadequate usage of French fashion terminology by a male person, cf.:

LOHENGRIN. 22/18-22

Mein' Meinung hab' i g'sagt, werd' g'scheidter,

Versetz' Dich aus der Neglijour

Jetzt in die schönen Kleider.

Ich hab' ganz neue kauft Dir Zwaa,

Ein's Sammet, 's andre poul de soire [.]

The expression poul de soire (only once attested in the Nestroy-Corpus) for French poule de soir[e] 'prostitute' is used instead of pou-de soie 'silk'. The absence of the final -e could be Nestroy's misspelling or even a minor alternation of the taboo term due to censorship. In the same passage Lohengrin tells Elsa 'to get out of her Neglijour', a blending word-formation from French négligé 'dressing gown' (the common French term is déshabillé) and French-like -jour, probably with a twofold motivation: French jour 'day' and/or the, the German suffix -ur (<French -ure) in analogy to similar German terms of French origin, which were common in a ladies boudoir, such as Frisur 'hairstyle, coiffure', Pompadour 'a handbag' $\left(18^{\text {th }} \mathrm{c} .+\right) .{ }^{17}$

\subsubsection{Stylistic accumulation and innovation (word-formation, morphosyntax and semantics)}

\section{a) Accumulation of suffixes}

A common feature in Nestroy parodies is the inflationary usage of certain derivational suffixes, e.g. the 'French style' (partly technical used) derivations in -i(e)ren; koramisieren, schagrinieren, bonmotisi(e)ren, sich divertieren, pilgrimisieren, quacksalberieren, verxanthippieren ${ }^{18}$ or the "iterative" prefixation: e.g. ver- in 'double compounds', secondary derivations, or in sequences: vertrincken - verfressen - verschlafen - verunterhalten („Der Zerrissene“, I,3).

The first type is rather frequent in Tannhäuser und Lohengrin, e.g. Tannhäuser in the first act (7/2930) „Wo ich, da ich mich schrecklich ennuyirte 'was getting bored; feel uncomfortable', die so

\footnotetext{
${ }^{17}$ Another possibility could be a word-play with German Montur, initially 'protective clothes (for miners), working clothes, military uniform', in colloq. use also humoristically for 'gear, clothes' with a collective meaning.

${ }^{18}$ Cf. also Hofmannsthal, Der Rosenkavalier: „Man retiriert sich jetzt von hier“; or the word cascade of the Advocate Blind in Strauß/Genée Die Fledermaus, and in Zar und Zimmermann by Albert Lortzing.
} 
gemütliche Lokalität hier etablirte 'established'“, but in both parodies we miss the typical wordcascades with the same prefix.

In the comedies of Aristophanes, this device is known by the accumulation of the suffix -ikos, the pleonastic use of which was a characteristic feature of the 'philosophical discourse'. ${ }^{19}$ Although the German -isch-suffix in general does not possess a marked use similar to -ieren,

In Tannhäuser (25, 1-8) encounter two erudite -isch compounds: mordionisch 'murderous, brutal' (4x in the Nestroy Corpus, instead of the common mörderisch) and platonisch 'platonic', which create a break in style, in the proverbially as witless and boring mocked song of Eduard und Kunigunde, already comically exploited and well-known to the public from Lumpazivagabundus (1833) and Der Feenball $(1833)^{20}$ :

Der Sängerkrieg:

WOLFRAM (steht auf, sieht sich grüßend um, nimmt die Harfe und singt schmelzend).

Eduard und Kunigunde,

Ihr der Liebe Musterpaar,

Lehret mich in dieser Stunde

Liebe singen rein und wahr.

Seufzen, sehnsuchtsvoll, mordionisch,

Glücklich sein in Lieb platonisch ${ }^{21}$,

Wenn d' Geliebte ein' auch verschmäht,

Oder mit ein' Andern geht.

An example, which combines both elements, suffixation and learned pun, occurs in Fridolin's lines from Tannhäuser:

Halt ein, Tannhäuser! Du willst uns kompromittiren,

Das duld ich nicht, drum werd ich mich prostituiren.

For certain, we deal here with the first reaction of the audience caused by the taboo-term and at the same time with the original, etymological and 'neutral' meaning of prostituiren, i.e. 'to place oneself in front', which must have reached those spectators, who were proficient in Latin, as learned pun. (for similar phenomena see under e) semantic ambiguity, below)

Another learned suffix occurs in Tannhäusers line "O nein! Das bin ich nimmer mehr kumpafel" (17/2). the meaning of this neologism kumpafel can be probably derived by a 'étymologie croisée' from Kumpel 'pal, mate', and Bafel, bafel 'nonsense' and in analogy to adjectives ending in -abel cf. probabel, with a meaning 'comradely', or in connection with kapabel meaning 'capable' (cf. also Branscobe 2000, 173).

b) Although Motionsfeminina beyond the linguistic 'norm' used by Nestroy (and achieve a rather rural connotation) are not uncommon, e.g. Heuchlerin, Ungeheuerin, Schlangin („Liebesgeschichten und Heurathssachen"), in Tannhäuser we find the occasionalism Philomenerich - already in Wollheim's version of Tannhäuser - "the he Philomene, outdated use for "nightingale", as a Motionsmaskulin for the bird name, in analogy to Gänse-rich 'gander' ( < Gans f. 'goose'), with a rather scientific touch and Nestroy's more vulgar neologism Philomele-rer (24/15) with the same meaning.

c) Compounding:

The 'Nestroyan' ad hoc-compounds are considered the most characteristic creative device of the playwright and are undoubtedly the best-researched feature from the point of view of linguistics (cf. Dressler and Tumfart 2017ab). ${ }^{22}$ As far as the Wagner-parodies are concerned, we want to highlight two groups of compounds. In the first case, there is a significant difference in the usage of the Zukunfts-compounds, which refer to the composer's concept 'music of the future', in the two parodies:

In Tannhäuser occur 11 tokens und 8 types in total, 7 of which are comic neologisms with a utopian touch, such as Zukunfts-hirsch (lit. 'future-deer'), while in Lohengrin we find only 3 Zukunftscompounds, which in fact all of them are in the stage directions.

\footnotetext{
${ }^{19}$ Cf. i.a. Aristophanes, Knights 1378ff.: sunert-ikos 'concise'; perant-ikos 'convincing', gnômotup-ikos '(using) rich phraseology', kroust-ikos 'clear and to the point', katalêpt-ikos tou thorubêt-ikou 'he knows well, how to quell an interruption'.

${ }^{20}$ Eduard und Kunigunde is already employed by Wollheim, probably as a well-known parodistic device through Lumpacivagabundus, thus Nestroy cites himself but also follows the Vorlage at the same time.

${ }^{21}$ In Wollheim's version: Nicht französisch oder spanisch, Nein nur christlich und germanisch.

${ }^{22}$ Cf. Dressler and Tumfart 2017b: 103 of Nestroy's compounds are formed according to fully productive word-formation patterns, only 1 in analogy to an unproductive pattern and only 2-3 are ungrammatical and 1 partially extragrammatical.
} 
T: Zukunfts-Musik (1x); Zukunftsmusik (3x); Zukunftshirsch (1x; lit. 'future-deer'); Zukunftskomposition (1x; lit. 'futurecomposition'); Zukunftsmax (1x; 'future-Max', character in Freischütz); Zukunftsoper (1x; lit. 'future-opera'); Zukunftsposse (1x; lit. 'future-Posse'); Zukunftsschneider (1; lit. 'future-taylor'); Zukunftszauberflöte (1x; lit. 'future-magic flute') (Entstellung eines Meisterwerks durch überzogene Ansprüche an den Sänger des Tamino).

L: Zukunftsritter, Zukunftsfrauen, Zukunfts-Fräuleins (6/10)

It seems that Nestroy did not overstress the inflationary Zukunfts-compounds in the lines of the characters in Lohengrin, in order to avoid a theme repetition. ${ }^{23}$

Another subtle stylistic device that can be traced in the Nestroy-Parody-Corpus is the relatively high frequency of a special category of compounds, the use of which can be explained as an element that intensifies the 'clash' of Wagner's medieval world with Nestroy's parodistic modernisation of the archaic theme. This is achieved by the coinage of 'modern' nominal determinative compounds, which in most cases display a hyphenation (German Bindestrichkomposita) or are innovative 'multiword-compounds' < 'double compounds: Ritter-Renomée 'knight-reputation' (L15/23); HarfenistenKampfplatz 'harpist-arena' (T 19/12; Humpen-Zahl 'tankard-number'(L 20/17); Ritter-Sommer-Hose 'knight-summer-trousers'(T 14/7); Coloratur-Geschnirkel 'coloratura-lavishness'; Slivowitz-Ruine 'Slivovitz('plum-brandy')-ruin' (T 31/23; refers to Tannhäuser as a desperate drunk after his futile journey to Rome). These compounds evoke a contradiction, not only because of their innovative content, but also as a novel type of compounds: although very productive in Modern High German these determinative compounds emerged in Early Modern High German (cf. Schindler 1999) and must have been a marginal and a marked category - in most cases - with a scientific connotation in Nestroy's times.

In the X- \&YZ gapping construction Soir- und Matineen we deal with a structure based on a shared ending of two French words, while the Heimat-Wonnelieder 'homeland-bliss-songs' (an allusion to Goethe's Faust) is a combination of a gapping Heimatlieder \& Wonnelieder, which again results to a compound.

\section{d) Morphological/Morphosyntactic ,Hypercorrection“}

Nestroy employs in Tannhäuser one of the most prominent features, where morphological or morphosyntactic constraints are violated in order to achieve a 'higher' or 'hypercorrect' speech level.

ELISABETH (erschrocken).

Wer ist's? - Ach Sie sind es, mein Lieber?

Was raschen Sie mich denn so plötzlich über?

In this case the compound verb überraschen is used as in the case of the German 'separable' verbs, which place the prefix/first compound member at the end of the clause (Satzklammer) in interrogative sentences and hypotaxis. Similarly, heu-zu-raten instead of $z u$ heiraten 'to marry' and the ungrammatical prefixed perfect form ge-missbraucht habe ich 'I have misused ...' (T 32/11).

\section{e) Semantic ambiguity/similarity, oxymoron}

Finally, we present here further cases of wordplay and puns based on semantic criteria creating (pseudo-)scholarly effect or mocking epic images and style, which we highlighted in our corpus next to the personal names (see 2.1. above). The use of 'minimal' pairs and/or blending is evident in the ad hoc modification of Elsa name as Edlsa (L 25/6), cf. edel 'noble' while the use of the verb kneipen 'to visit a pub' (here: the mountain of Venus), must have amused the Viennese audience by evoking the connection with kneippen 'to undergo a Kneipp-therapy', an anachronism similar to the consumption of Champagne (or even of Röderer, name of a champagne brand in L 16/9). Similarly, in T 9/14-15: „Gemütlich brüllt der Rinder traute Herde, o, was für Ochsen gibt es auf der Erde!“ we deal with word-play based on the substitution of Rind 'cow' by Ochse 'ox' and the ambiguous semantics of the latter used in an insulting sense. Going beyond the lexeme level, in Tannhäuser's aria (13/18-19) we find „Freiheit und Tatendurst, Schinken und Leberwurst" "Freedom and action-thurst, ham and liversausage" the (-thurst functions as a 'hinge', which connects the noble content with gastronomy). Again, in T (8/27) ,und die Gewissensbisse fangen an zu beißen" "and the pangs of conscience start to pang me" Nestroy makes use of an ironic, trivialising etymological figure, while in „Ich nehme in Ekstase mich prüfend oftmals bei der Ritternase“ (7/12-13) the pun exceeds the lexeme level by integrating and alternating a whole idiomatical phrase: sich an der (eigenen) Nase nehmen (esp. Austrian German) 'to practise what one preaches'.

\footnotetext{
${ }^{23}$ In T 24/9-10: „Machts mit der Stimm' nur keinen Gix, am Text, o mein! Da liegt ja nix“ is an allusion to the notorious challenges faced by the singers of Wagner, and the incomprehensibility of the sung text.
} 
In the romantic formula „Lieb' liebt Blümlein fein,“ (T 26/9-10), the noun Blümlein 'little flower' is followed by the adjective fein (similar to „Röslein rot" 'little rose red'), and is counteracted with Schmalz-blümelein (Caltha palustris) 'lard, schmaltz'-flower evoking the connotation of fat, greasy food and 'cheesy' singing. The connection of Blümlein with Schmalzblümlein might have been triggered by the variant of the flower name Butterblume (cf. also Engl. buttercap), which contains the rather 'refined' term Butter compared to Schmalz. Furthermore, we encounter partially modified set pieces from colloquial speech, such as „beim Schnurr-bart(!) ('moustache') des Propheten“ (T 34/3334) instead of Bart(e) 'beard'. The oxymoron, as a characteristic Nestroyan feature is employed in the parodies as well, esp. based on cultural contradictions cf. arabisches Dänenro $\beta$ 'Arabic Dane-horse' T (17/23) (see also below, under 2.3.3)

\section{f) Dramatic characterisation}

The third criterion of technicality that is specific to comedy is the occurrence of potentially technical lexemes in passages that have a characterizing function. Here it is not even necessary that the words of a stage figure are comprehensible to the audience. When the language of a stage character has no other function than to portray him as a specialist in a certain field (while the contents of the utterance are irrelevant), the comic playwright is free to introduce as many obscure technical terms as he likes - or to invent pseudoterms.

Although this factor plays an insignificant role in Nestroy's parodies, nevertheless we find elements of characterisation through the usage of technical vocabulary, even in a category, which was hardly relevant in the Old Comedy: In Nestroy we frequently come across the usage of medical terms, which were widely integrated into the everyday speech of the $19^{\text {th }}$ century, while the occurrence of secured medical terms in the Aristophanic corpus is rare.

Tannhäuser 34/12:

WOLFRAM (entsetzt). Mich rührt der Schlag, Apoplexia genannt, O Heinrich, sei doch nicht so desperat.

The medical term Apoplexia 'stroke, apoplexy', Greek apoplexía, is used by Wolfram after he has introduced of the lexeme with a preceding paraphrase Mich rührt der Schlag 'I'm am affected by the stroke'. The Greek loanword, which has been adopted in German as Apoplexie, displays here the Graeco-Latin ending - $a$, which enhances the 'scientific' touch of its usage.

The dramatic characterisation through specialised vocabulary is not limited to medicine only. In Aristophanes, for instance, where this feature is rare, characterisation of the dramatis personae is also achieved by the implementation of other high linguistic registers, such as the philosophical discourse and even the poetic vocabulary of Homer, i.e. specialised vocabulary can be summarised as a combination of technical and scholarly terms. Parallel to the use of (par)etymological attempts, as a prototypical practice employed by erudite people, in Nestroy's parodies, we encounter several, in many cases subtle, allusions to the educational level of the stage characters, e.g. the "unknown quantity/variable' $X$ used by Lohengrin and subsequently explained by Elsa with 'anonymous' presupposes a mathematical term, which was - even if not used by everybody - at least understandable to the general public.

Lohengrin 25/14-17

LOHENGRIN. Zu was? Der Nahme thut zur Sache nix, Nenn' mich, als unbekannte Größe, ,, $X$,,. ELSA. So ein Liebesbund macht doch ka rechte Freud'; Mich reizt nicht anonyme Seeligkeit.

Finally, although Latinisms are not absent in Nestroy's parodies, e.g. nisi 'if not' 'premise' (L 12/19), we miss the code mixing/switching of 'Latinisms', and similar 'hybridic patterns', which Nestroy employs in other plays, such as tempus mutampus (Liebesgeschichten und Heurathssachen I,11), kennimus nos (Alles will den Prophet'n seh'n I,9), o heuchlerisches codicil - Krokodil, will ich sagen (Lady und Schneider II,22)

\subsubsection{Gender specific language: female speech}

Undoubtedly, gender is a further criterion for the classification of the linguistic features of comedy and their employment. The gender-preferential features in the language of the Aristophanic comedies are very conclusive. Especially, in the case of female speech, we clearly are in a position to distinguish between three groups, concerning the following linguistic domains, namely, 'politeness', 'colloquialism' (even 'obscenity') and linguistic innovation, not only on a lexical but also on a syntactic level. 
Research conducted by now shows that Nestroy's female characters are in general multi-facetted ${ }^{24}$, although an overall, corpus-based study remains a desideratum. Although, it would be methodologically inadequate to draw conclusions for the female speech in the entire Nestroy-Corpus, as far as Nestroy's Wagner parodies are concerned, we conducted a comparison between the male (T: 3119; L: 2081 words) and female parts (T: 621; L: 1151 words), according to the aforementioned criteria. The results showed a well-balanced qualitative and quantitative distribution of linguistic features, such as colloquialism, use of dialectal elements or linguistic innovations. Even in the case of '(negative) politeness', which is a well-documented phenomenon of female speech in the ancient comedy, there exist no traceable linguistic differences between the genders in Nestroy's parodies. Elisabeth in Tannhäuser (19/18-19) is portrayed as a bluestocking à la mode: „Konzerte, Kränzchen, Soir- und Matineen, in alles dies tat ich nicht mehr gehen" "concerts, ladies' coffee parties, soirees and matinees [Soir- und Matineen cf. also the gapping discussed above] to all of them I wouldn't go anymore" and combines her deep sorrow with calm domesticity in a very sophisticated pun, cf. Tannhäuser (29/10-11):

„Die Sehnsucht und die Strümpfe, sie stopfen sich so schwer!“ 'The nostalgy and the socks, both are difficult to mend'.

In general, women are presented as being intellectually equal to the male characters. Lohengrin (with disapproving dismay, though) contends to Elsa: Du bist ja gar ein naiver Schneck! (L 25/27),

and seems to be aware of the domestic duties (L 24/30):

Die Vorhäng sind beym Putzen,

Drum scheint der Mond herein.

'The curtains are at the laundry,

That's why the moon shines in'

Of course, in the case of Tannhäuser and Lohengrin we primarily deal with 'noble ladies' and the most important factor is that Nestroy's intention is a parody, which aims at targeting Wagner's style in general, and not study on different milieus of his time. Here, we cite an example from Lohengrin (21/2-3), where Gertrude appears well-versed in learned contexts by using words such as Gedankenstrich 'indent' (following Fragzeich'n 'question mark':

GERTRUDE (zu LOHENGRIN).

O, Sie habn's nöthig, daß Sie so aufblasen sich,

Sie Ritter, Sie, mit Fragzeich'n und Gedankenstrich. (1x Nestroy Corpus)

Nestroy also presents women capable of dealing with scientific vocabulary, cf. Elisabeth's knowledge of the term chloroformiren 'to chloroform' in Tannhäuser (30/4-9):

ELISABETH (verzweifelnd).

O Wolfram, komm, chloroformire mich!

WOLFRAM (sanft).

Ich soll sie chloroformiren

In einen tiefen Schlaf,

Ich darf nicht practiziren,

Das kost fünf Gulden Straf.

At the time, when Nestroy wrote Tannhäuser, in the year 1857, the term chloroform had been published only three years before in the respective scientific journals, but it was already well-known to the general public since 1853, when it was given Queen Victoria during child birth.

At this point, we want to stress out that the distribution of neologisms or other comic elements in Nestroy's plays, could have possibly been influenced by a rather banal reason, but which should not be underestimated: the playwright chose the arrangement of the comic elements with regard to the respective actor's performing skills. According to Dressler \& Tumfart (2017a, 163) the distribution of occasionalisms shows that Nestroy must have kept several comical highlights for his own parts. Further, the linguistic features used for highlighting female speech in Nestroy's theatrical corpus still remain unexplored.

\subsubsection{Other registers}

a) Simplified registers. Two of the most common simplified registers are 'baby talk' (adults to small children) and 'foreigner talk', which includes the way native speakers often use towards foreigners, cf. the 'Scythian Greek' in Aristophanes' Thesmophoriazusae (Willi 2003, 198-231). With the

\footnotetext{
${ }^{24}$ Cf. i.a. Yates 1985, Tanzer 2006, Maierhofer 2012.
} 
expression Dingsda (cf. 2.3.) being the only expression, these two registers do not occur in the Nestroy parodies, probably due to the fact that the plot in Wagner's operas does not support these aspects. Nevertheless, they are attested in the Nestroy-Corpus, e.g. in the pseudo-Italian used by Zwirn (Lumpacivagabundus II,16) Zani kani (keine Zähne 'without teeth', Gestutzte orecchi ('trimmed ears').

b) Prestigious loanwords/dialectal code-mixing: the social setting in Nestroy's times is predominately characterised by foreign, i.e. Latinisms and French, prestigious vocabulary, which alternates with dialectal features of the Viennese dialect, varying between i) Austrian German forms mixed with other elements of colloquial style or/and officialese in order to trivialize Wagner's style, for instance in Wolfram's famous „Lied an den Abendstern“ (T 30/26-29), where the poetic evening star becomes a Guter Mond 'good moon', and instead of „du gehst so stille“" 'you go so quietly' in the original, Nestroy continues with „du goldner Zwiebel“ "you, golden onion!” (here used as masc. noun, common in Austrian German in contrast to Standard High German die Zwiebel, contained in Wollheim's version), which is followed by the coll. expression gar nicht übel 'not that bad', and the addressing of the evening star as hochgeehrt 'highly honoured', like in official correspondence, and ii) taboo expressions, cf. Tannhäuser (35/29-30) „Ich folg' dir in die Gruft der Ahnen ${ }^{25}$, und dich, Frau Venus, lass' ich unten lahnen“ lahnen Viennese dial. for lehnen 'lean on', is an innuendo for the vulgar expression: „ein Mädchen verlassen ang 'lahnt lassen“). The urban-rural gap is also evident, cf. the stereotypic opening for mounteneers' songs in T (25/19-22) „Dort drobn aufn Berg ... “ ("there, upon the mountain..." in contradiction to the Viennese "Grätzel“" setting Himmelpfortgrund (former autonomus community in the $9^{\text {th }}$ Bezirk) and the oxymoron bürgerliche Landgrafensnichte 'bourgeois landgrave-niece' .

We encounter two cases with Northern German prominent dialectal features /j/, / $/$ instead of /g/ and /ç/, and the characteristic for speakers from Germany final /-iç/ instead of the Austrian (and Southern) German counterpart /-ik/.

Lohengrin 15/33-34

MORDIGALL.

Du logst mir Elsa's That, ob der ich mich geharnischt,

Und jetzt zeigt sich der ganze Brudermord als jar nischt [gar nicht].

... MORDIGALL (erschüttert)

Die laute Fest gaudée ist unerträglich,

Des Feindes Jubel ist doch gar zu ecklich [ecklig]!

Further: grantich $\sim$ grantig in L 30/3

Tannhäuser 16/23-25

TANNHÄUSER

Es jing [ging] wohl, aber's jeht [geht] nicht, gnäd'ger Herr!

WOLFRAM, WALTER und FRIDOLIN.

Es jing wohl, aber's jeht nicht!

c) The religious registers, which are considered a central aspect in the historical corpora from the antiquity and especially in the comedies of Aristophanes, are not prominent in the Nestroy's parodies: Inevitably, the Viennese playwright had to omit religious motifs and connotations, which were actually part of Wollheim's version, due to prior censorship and because of the fact that his play was meant for an official theatre in contrast to the German students parody (cf. Branscombe 2000, 49). Breaks in style by employing innuendos to pious or conservative motifs are very subtle in Nestroy's version, for instance, the resurrection and engagement of Elisabeth und Tannhäuser as a mixture of religious context and 'Punch and Judy show' or the bridal bouquet symbolising virginity (Jungfernkranz) for the sinning goddess of love, Venus, in the Nymphenchor. ${ }^{26}$

However, in our corpus we find at least one allusion to a religious quotation:

Tannhäuser 27/6-12

PURZL, WOLFRAM, WALTER, FRIDOLIN und CHOR.

Ergreift das erste Beste

Und klopft ihm aus die Weste

Im donnernden Gebraus,

Werft den Verräther raus.

\footnotetext{
${ }^{25}$ With possible allusion to Grillparzer's dramatic play Die Ahnfrau.

${ }^{26}$ Based on the well-known bridesmaid chorus from Weber's Freischütz.
} 
ELISABETH (mit lautem Schrei).

Haltet ein, wer wirft auf ihn den ersten Stein!

'Hold on, who casts the first stone at him! ( NT, John 8,7)

The cases, where (quasi)quotations originate from classical German authors or from Wagner's works, have been thoroughly investigated in Branscombe (2000, 51-59) for Tannhäuser, as compared to Wollheim's text, here we refer just to one example from Lohengrin a.o. „Wie, hör' ich recht?“ L 27/4 (original citation from the Flying Duchman).

\section{$3 \quad$ Parody and original as compared corpora}

The topics discussed above can be summarised as follows: After searching and analysing the complete text of the Nestroy Parody corpus according to pervasive linguistic characteristics of Nestroy's plays in general, and on how those features are functionally connected to genre specific registers, which conform to the culturally expected way of constructing texts belonging to the variety 'parody', as described by Willi (2003) for the Language of Aristophanes, we were able to demonstrate a significant resemblance, between Nestroy's plays and the Old Comedy.

\begin{tabular}{|c|c|c|c|c|}
\hline $\begin{array}{c}\text { Linguistic registers } \\
\& \\
\text { features* }\end{array}$ & Aristophanes & $\begin{array}{l}\text { Nestroy's } \\
\text { Wagner } \\
\text { parodies }\end{array}$ & $\mathbf{T}$ & $\mathbf{L}$ \\
\hline Technical Languages & YES & YES & & \\
\hline Medical terms & RARE & YES & 2 & - \\
\hline Comic misunderstandings & YES & YES & 1 & 1 \\
\hline $\begin{array}{l}\text { Accumulation of formally similar } \\
\text { words }\end{array}$ & YES & YES & 2 & 2 \\
\hline Characterising passages & YES & YES & & \\
\hline Scientific Discourse & YES & YES & 13 & 6 \\
\hline $\begin{array}{l}\text { "Sophistic Innovations“/folk } \\
\text { etymology }\end{array}$ & YES & YES & - & 2 \\
\hline Female Speech & YES & $?$ & & \\
\hline Politeness & YES & $?$ & & \\
\hline Colloquialism & YES & $?$ & & \\
\hline Linguistic Innovation & YES & $?$ & & \\
\hline Dialects & YES & YES & 10 & 23 \\
\hline Foreigner talk/foreign dialects & YES/ YES & NO/ YES & 1 & 2 \\
\hline $\begin{array}{l}\text { Prestigious } \\
\text { loanwords/bilingualism }\end{array}$ & NO & YES & 10 & 5 \\
\hline Religious registers & YES & YES & 1 & - \\
\hline Speaking names & YES & YES & 5 & 4 \\
\hline
\end{tabular}

Table 1

In table 1. above, the first column from the left is a summary of the major Aristophanic elements (following Willi 2003) together with two further 'Nestroy-specific' features (prestigious loanwords/bilingualism), while the next two middle columns display the occurrence (or absence) of these features in Aristophanes and in Nestroy's Wagner-parodies. On the categories pertaining to female speech see under 2.3.2.

In the two last columns on the right we expanded the 'qualitative' criterion (i.e. the occurrence of certain pervasive linguistic characteristics) to the quantitative one, by listing the number of occurrences of each feature in Nestroy's Tannhäuser and Lohengrin respectively, in order to highlight 
their distribution in the two plays, where we can observe that while some features are balanced, the use of scientific language and the dialectal elements may differ.

As a last stage of our investigation, we wanted to answer the question of the overall (co)relation between original play and its parody and which methods and tools of corpus linguistics are available for this kind of studies. Interestingly, although the strategies for describing and comparing corpora have improved in the last decade and several computational tools promise various possible applications for comparisons between different kinds of corpora, i.a. also for different genres, the existing studies on parody and transtextuality in general are very scarce. Here, we refer to one of these exceptions, namely the stylometric study by Christoph Schöch on the pastiche of French crime authors (by other French authors). The striking outcome of this stylometric investigation is that the product of the pastiche is much closer to the individual style of the 'imitating' author, as to the work(s) of the original author, i.e. even if we try to imitate the language use and style of someone else, the final product will reveal our own stylistic fingerprint. In any case, it seems that stylometric tools cannot be fooled by imitating authors.

Taking these findings under consideration and since parody is the satirical variety of the pastiche, we tested our Nestroy and Wagner corpora under the Compare Corpora function in Sketch Engine (attribute: lemma) ${ }^{27}$ according to Kilgariff's (2001) score model, the highest resemblance and the most significant correlation display Wagner's Tannhäuser and Nestroy's Tannhäuser with a factor 5.13 (still a white field), followed by Wagner compared to himself: 5.67 (medium grey field). Then come both Lohengrin versions with 6.52 (very dark grey field), which means that Nestroy did alternate much more in Lohengrin than in Tannhäuser. And at last, both Nestroy parodies differ very much from each other 6.55 (also in a very dark field). The results of the resemblance scores are in accordance with the linguistic data we have at our disposal and can be analysed as such: In Nestroy's Tannhäuser the influence of the Nothern German Vorlage, which obviously is close to Wagner's original, was adapted by Nestroy and mainly modified through single lexemes, whereas Nestroy's Lohengrin is a true example of a Lokalposse in the Viennese dialect: in the latter the playwright undertook his changes not only on the lexeme level, but also within the phrase structure. The comparison of the two Nestroy's parodies to each other supports these findings again and gives evidence of a different style between the two plays. Thus, the compared corpora functions seem to be sensitive to different styles, in our case they agree with the all over first impression of the early scholarship on Nestroy that the anonymous Tannhäuser might not have written by him. Only after a thorough investigation of selective modifications the stage play has been considered as 'Nestroy-like', but the overall style is still influenced by Wollheimer.

\section{$4 \quad$ Summary and outlook}

From the point of view of corpus linguistics the results could be summarized as follows:

a) In our aim for a comprehensive account of the poetic licenses and style in Nestroy's parodies, we did not just examine isolated phenomena, but we concentrated on a set of features and parameters (following the methodology by Biber/Conrad 2009, 31-47; Biber 2010). We went beyond the questions of grammar proper, such as morphology, semantics, and syntax, and tried to focus on the language use employed by the dramatis personae, including register and gender. In order to check the comic elements in their general validity, we compared Nestroy with his ancient counterpart, Aristophanes, where the obtained results reflect a high conformity.

b) As far as the genre is concerned: the comic elements occur not only in the characters' lines, but also in the list of the dramatis personae and the stage directions. While the mocking of the characters' names is relevant, since they are an important part of the actual stage play, Nestroy's parody targets Wagner's style beyond those passages, which were meant for the audience.

c) After documenting the situational characteristics for register included in the parody parallel to the identification of the set of linguistic features included in the analysis, we utilized resemblance scores in order to answer the question on how the involved corpora compare to each other on the stylistic

\footnotetext{
27 value "1" (white colour field) means identical corpora; the higher score \& the darker color, the greater difference between corpora ("4" does not mean twice as many as "2"), cf. https://www.sketchengine.eu/user-guide/usermanual/corpora/compare-corpora/\#toggle-id-2
} 
level. Corpus linguistics nowadays offers various ways in which different corpora can be compared more objectively. In particular, we are in a position to describe and compare a parody with its Vorlage and adequately answer questions of style and authorship, which in the past could only be treated impressionistically. For instance, although Tannhäuser is considered Nestroy's successful parody, in which many occasionalisms occur, we suggest that Lohengrin has been much underestimated in its literary quality.

Moreover, parody can be an advantage in studying not only the comic elements in stage and the language of humour, but also as an indicator for measuring rewriting processes, intertextuality and style within corpora. In other words, the parody of a style or linguistic variety often highlights its peculiarities. Since our pilot study involved a small corpus, only further investigations and dimension scores could bring to fore differences between other works 'paraphrased' by Nestroy (such as the travesty Judith und Holophernes, and the parody of the Zauberposse Robert der Teuxel) and finally with the rest of his works. For the time being, a large scale corpus-based investigation, which tracks down the poetic licenses employed by Nestroy while at the same time regards sociolinguistic factors, such as register, genre as well as diachrony, and describes his language use through his time as an active playwright still remains a desideratum. Nevertheless, the results on Nestroy's language, which we have at our disposal so far, indicate not only similarities but also several linguistic differences between the parodies and other Possen of the Viennese playwright: In Tannhäuser and Lohengrin we encounter several ad-hoc compounds, but we miss several subtypes of 'Nestroy specific' wordformation, e.g. neologisms based on verbs derived from two part syntagms or nominal compounds: saltomortalisiren (Jux, III,12), dejeuneralaforschettelt (Eisenbahnheiraten, I,3); 'densifying' nominalisations of propositional contents: e.g. intel(l)ectueller Zurseitensteher (Talisman, II,17), bedientenhändige Entfernung ihres Geliebten (Liebesgeschichten und Heurathssachen, II,15); the use of gerundives: von dem Gebildetseynsollenden ... Theil (der Menschheit) (Jux, I,10); von der dem Vater zu verabreichenden ...Atzung (Die beiden Nachtwandler, II,25) or (participial chain): die verstorb'ne Garderob von ihrem überstandenen Gemahl (Talisman, II,6), and finally the Schema Nestroyanum $^{28}$ : e.g. schülerischer Meister (Der Talisman); blasender Instrumentenmacher (Eisenbahnheiraten I,3). Again, the absence of these Nestroy's 'favorites' could be explained by the fact that the themes and the characters in Wagner's operas did not support the use of these occasionalisms. After all, parody distorts and exaggerates, but it does not invent or as Willi $(2003,5)$ contends: "Parody is not faithful in degree, but it is faithful in kind".

\section{References}

Barton, Anne. 1990. The names of comedy. University of Toronto Press, Toronto.

Biber, Douglas. 2010. What can a corpus tell us about registers and genres? In: Anne O'Keefe \& Michael McCarthy (eds.) The Routledge Handbook of Corpus Linguistics. Routledge, London, 241-254.

Biber, Douglas and Susan Conrad. 2009. Register, Genre and Style. CUP, Cambridge, UK.

Branscombe, Peter. 2000. Johann Nestroy Stücke 36. Tannhäuser. Herausgegeben von Peter Branscobe. Deuticke, Wien.

Branscombe, Peter. 2001. Johann Nestroy Stücke 37. Lohengrin. Zeitvertreib. Herausgegeben von Peter Branscobe. Deuticke, Wien.

Campe, Joachim Heinrich. 1807. Wörterbuch der Deutschen Sprache, Bd 1. A-E. Braunschweig.

Culpeper, Jonathan. 2001. Language and Characterisation. People in Plays and other Texts. Routledge, London.

Dressler, Wolfgang U. and Barbara Tumfart. 2017a. New corpus-linguistic approaches to the investigation of poetic occasionalisms: The case of Johann Nepomuk Nestroy, Yearbook of the Poznań Linguistic Meeting 3 (2017): 155-166. DOI: 10.1515/yplm-2017-0008

Dressler, Wolfgang U. and Barbara Tumfart. 2017b. Johann Nepomuk Nestroy (1801-1862) als großer Wortbildner. Neue korpuslinguistische Ansätze für die Auswertung okkasionalistischer Neubildungen, in: Zeitschrift für Literaturwissenschaft und Linguistik, Volume 47, 4: 563-594.

\footnotetext{
${ }^{28}$ Cf. Panagl (1983): A not uncommon characteristic of Nestroy's involves the utilization of a variant of 'decomposition', which occurs according to the following stages: 'loosening' of a word-formation, which initially obeys the morphological rules of German, parallel to the 'cancelation' of the semantic lexicalization, and final recombination resulting in a novel two part syntagma; see also Hunger (1999).
} 
Hein, Jürgen. 1990. Johann Nestroy. J. B. Metzlersche Verlagsbuchhandlung, Stuttgart. (Sammlung Metzler, Bd. 258).

HKA = Johann Nestroy: Sämtliche Werke. Historisch-kritische Ausgabe. Hg. von Jürgen Hein, Johann Hüttner, Walter Obermaier und W. Edgar Yates. Wien 1977-2004, Nachträge I und II, Wien 2007; Nachträge I und II. Hg. von W. Edgar Yates und Peter Haida, Wien 2007; Register. Hg. von Johann Lehner, Wien 2010 [HKA]; Ergänzungen [Dreyßig Jahre aus dem Leben eines Lumpen; Der Weltuntergangstag; Die Familien Knieriem, Zwirn und Leim; Die schlimmen Buben in der Schule]. Hg. von Fred Walla und Walter Obermaier, Deuticke, Wien 2012.

Hunger, Herbert. 1999. Das Denken am Leitseil der Sprache: Johann Nestroys geniale wie auch banale Verfremdung durch Neologismen. Verlag der Österreichischen Akademie der Wissenschaften, Wien.

Kanavou, Nikoletta. 2010. Aristophanes' Comedy of Names. A Study of Speaking Names in Aristophanes. Berlin: de Gruyter.

Kilgariff, Adam. 2001. Comparing Corpora. International Journal of Corpus Linguistics, 6:1 (2001): 97-133.

Maierhofer, Maria. 2012. Männlichkeit und Weiblichkeit bei Nestroy Männlichkeit und Weiblichkeit bei Nestroy Eine interaktions-und praxistheoretische Re-Lektüre, Master-Thesis, University of Vienna.

Panagl, Oswald. 1983. (De-)Lexikalisierung und Paretymologie im Wortschatz Johann Nestroys. In: M. Dardano (Hrsg.) Parallela. Akten des 2. österr.-ital. Linguistentreffens: 64-79.

-2007. Poetische Lizenzen in der Wortbildung. In: Wolfgang U. Dressler \& Oswald Panagl (Hg.) Poetische Lizenzen. Praesens Verlag, Wien, 117-132.

-2009. Werk - Wirkung - Wandel. Zu den Gattungen Satyrspiel, Palinodie, Parodie, in: Der Werkbegriff in den Künsten : interdisziplinäre Perspektiven. hrsg. von Herwig Gottwald u. Andrew Williams. Wissenschaft und Kunst; 6. Winter, Heidelberg, 33-50.

Rommel, Otto. 1962. Johann Nestroy.Gesammelte Werke. Ausgabe in sechs Bänden. Schroll, Wien. [Photostat. Nachdr. d. Ausg. 1948 - 1949]

Schindler, Wolfgang. 1999. Bindestrich-Komposita im Frühneuhochdeutschen. In: Grippe, Kamm und Eulenspiegel. Fs für Elmar Seebold zum 65. Geburtstag, hrsgg von Wolfgang Schindler und Jürgen Untermann. de Gruyter, Berin/New York, 313-330.

Schneider, Andrea. 1996. Die parodierten Musikdramen Richard Wagners. Müller/Speiser, Anif-Salzburg.

Tanzer, Ulrike. 2006. Die Demontage des Patriarchats. Vaterbilder und Vater-Tochter-Beziehungen bei Johann Nestroy. In: Yates, W. Edgar/Dies. (Hgg.): Theater und Gesellschaft im Wien des 19. Jahrhunderts. Ausgewählte Aufsätze zum 25-jährigen Bestehen der Zeitschrift Nestroyana. Lehner, Wien (= Quodlibet 8), 153-164.

Willi, Andreas. 2003. The Languages of Aristophanes. Aspects of Linguistic Variation in Classical Attic Greek. Oxford University Press, Oxford.

Yates, W. Edgar. 1985. Nestroy, Grillparzer, and the feminist-cause. In: Yates/McKenzie, John R.P. (Hgg.): Das Wiener Volkstheater. Ein Symposium. University of Exeter. Wheaton \& Co, Exeter, 93-108. 